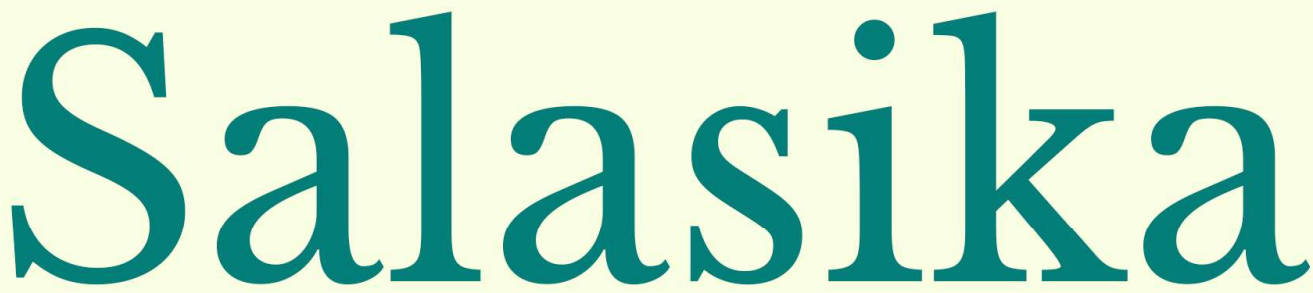

\title{
INDONESIAN JOURNAL OF GENDER, WOMEN, CHILD, AND SOCIAL INCLUSION'S STUDIES
}

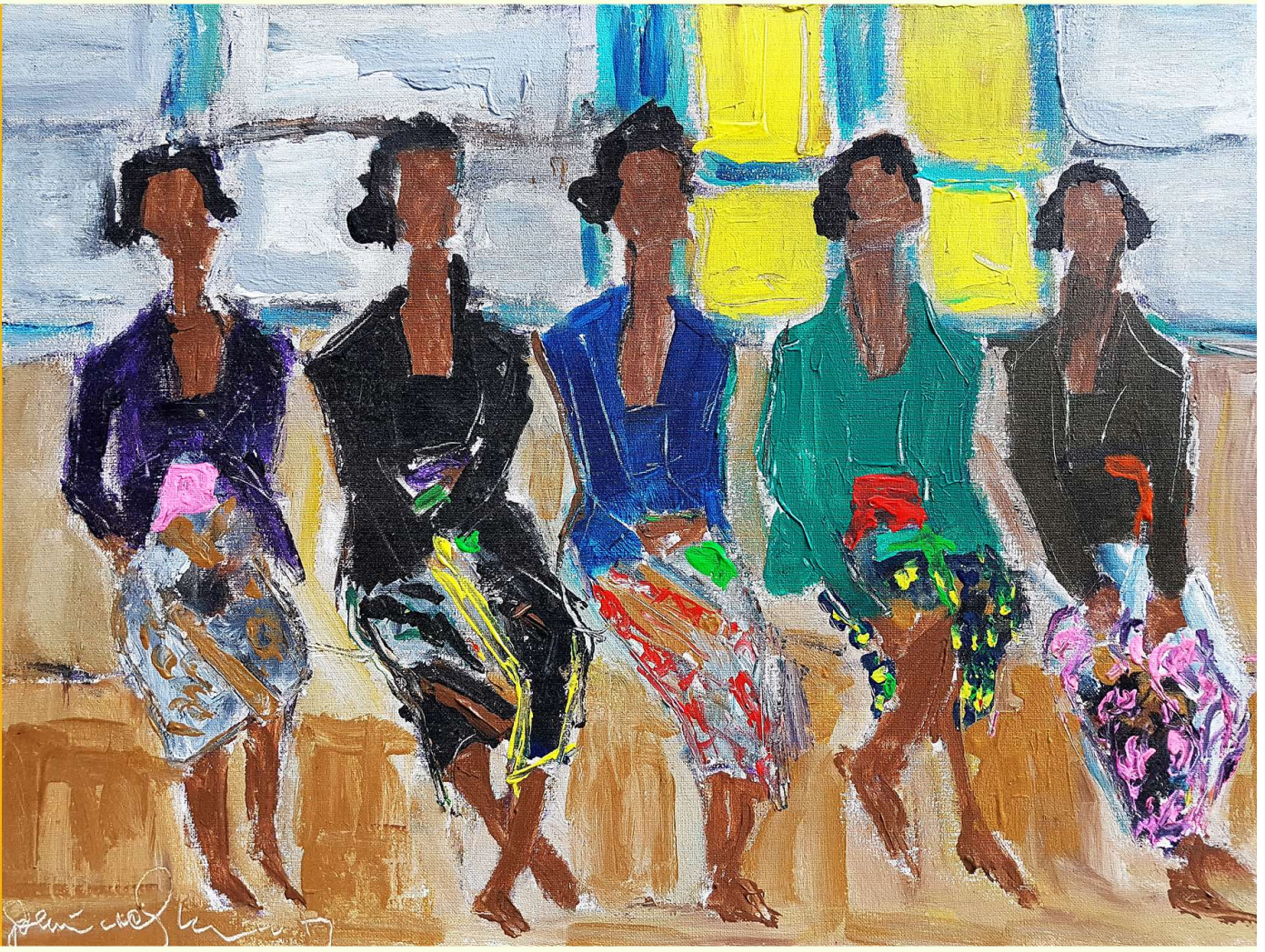

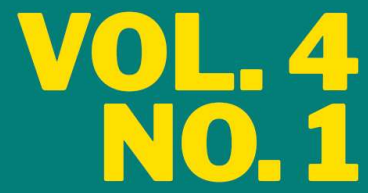

JuY 2021
Reviewing Batik with Natural Coloring based on

the Clean Production Theory with an Ecofeminist Perspective

(Case Study: Putri Kawung Batik Community in Klaten)

Purwanti Asih Levi, Arianti Ina Restiani Hunga, Hotmauli Sidabalok

The Inherent Link between Gender and Sexuality:

A Queer View to the Portrayal of Women in Herland, Things Fall Apart,

Bombay Brides, and The Winner Stands Alone

Suparna Roy

The Pattern of Early Childhood Character Education in Villages and Cities:

A Study in Tulungagung Regency, East Java

Keppi Sukesi, Jedda Ayu Inggrida, Iwan Nurhadi

The Urgency of Protection House for Women Victims of Violence

Helen Intania Surayda

The Effects of Corona Virus Pandemic on Children

Keneth Tumwesigye 


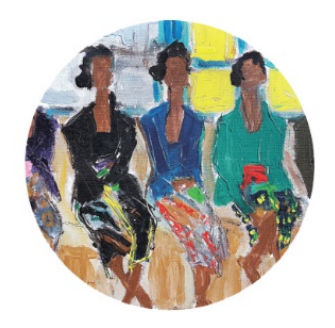

\section{Salasika \\ INDONESIAN JOURNAL OF GENDER, WOMEN, CHILD, AND SOCIAL INCLUSION'S STUDIES}

VOLUME 4, NUMBER 1 - JULY 2021

\section{Table of Content}

Reviewing Batik with Natural Coloring based on the Clean Production Theory with an Ecofeminist Perspective (Case Study: Putri Kawung Batik Community in Klaten)

Purwanti Asih Levi, Arianti Ina Restiani Hunga, Hotmauli Sidabalok

The Inherent Link between Gender and Sexuality:

A Queer View to the Portrayal of Women in Herland, Things Fall Apart, Bombay Brides, and The Winner Stands Alone

Suparna Roy

The Pattern of Early Childhood Character Education in Villages and Cities:

A Study in Tulungagung Regency, East Java

Keppi Sukesi, Jedda Ayu Inggrida, Iwan Nurhadi

The Urgency of Protection House for Women Victims of Violence

Helen Intania Surayda

The Effects of Corona Virus Pandemic on Children

Keneth Tumwesigye 


\section{Editorial Team}

\section{CHIEF EDITORS}

Arianti Ina Restiani Hunga, Universitas Kristen Satya Wacana, Indonesia (Scopus ID: 46161114400, Google Scholar)

Dewi Candraningrum, Universitas Muhammadiyah Surakarta, Indonesia (Google Scholar)

\section{BOARD OF EDITORS}

Claudia Derichs, Humboldt Universität zu Berlin, Germany (Scopus ID: 14026487800)

Ida Sabelis, Vrije Universiteit (VU) Amsterdam, The Netherlands (Scopus ID: 6507181398, Google Scholar)

Siti Kusujiarti, Warren Wilson College, USA (Scopus ID: 56276925900)

Ratna Saptari, Leiden University, The Netherlands (Scopus ID: 6504610910)

Sylvia Tiwon, University of California, USA

(Scopus ID: 6506468591)

Emy Susanti, Universitas Airlangga, Indonesia (Scopus ID: 57213142220, Google Scholar)

Keppi Sukesi, Brawijaya University, Indonesia (Scopus ID: 56025803300, Google Scholar)

Kristi Poerwandari, University of Indonesia, Indonesia (Scopus ID: 25628305200, Google Scholar)

Willemijn de Jong, University of Zurich, Switzerland (Scopus ID: 55258294800)

Lyn Parker, The University of Western Australia, Australia (Scopus ID: 56273266700)

\section{TECHNICAL EDITORS}

Indriretno Setyaningrahayu, Universitas Kristen Satya Wacana, Indonesia (Google Scholar)

Daniel Kurniawan, Universitas Kristen Satya Wacana, Salatiga, Indonesia (Google Scholar) 
Suryaningsi, Universitas Mulawarman, Indonesia

(Scopus ID: 57223402854, Orcid: https://orcid.org/0000-0003-1093-810X, ID Sinta: 5990865, Google Scholar)

Agustinus Fritz Wijaya, Universitas Kristen Satya Wacana, Indonesia (Scopus ID: 56461093400, Google Scholar)

Stefanus Perangin-Angin, Universitas Kristen Satya Wacana, Indonesia (Google Scholar)

\section{REVIEWERS}

Elisabet Titik Murtisari, Universitas Kristen Satya Wacana, Indonesia (Scopus ID: 38161752200, Google Scholar)

Asfa Widiyanto, IAIN Salatiga, Indonesia (Scopus ID: 56451676900, Google Scholar)

Wening Udasmoro, Gadjah Mada University, Indonesia (Scopus ID: 56493135600)

Farah Purwaningrum, The University of Sydney, Australia (Scopus ID: 57192369400, Google Scholar)

Alimatul Qibtiyah, Sunan Kalijaga State Islamic University, Indonesia (Scopus ID: 57200660732, Google Scholar)

Tyas Retno Wulan, The Jenderal Soedirman University, Indonesia (Scopus ID: 57205341358, Google Scholar)

Nurjanah,State University of Jakarta, Indonesia (Scopus ID: 57210948418)

Ira Desiawanti Mangiliko,The Artha Wacana Christian University, Indonesia

Keiko Hirano, Ochanomizu University, Jepang

(Orcid: https://orcid.org/0000-0002-3258-6072)

Anik Yuesti, Universitas Mahasaraswati, Indonesia (Scopus ID: 57214104250, Google Scholar)

Nurdiana Gaus, STIKS Tamalanre Makassar, Indonesia (Google Scholar)

Yacinta Kurniasih, Monash University, Australia (Google Scholar)

Yafet Yosafet Wilben Rissy, Universitas Kristen Satya Wacana, Indonesia (Scopus ID: 57221474276, Google Scholar) 


\title{
Reviewing Batik with Natural Coloring based on the Clean Production Theory with an Ecofeminist Perspective (Case Study: Putri Kawung Batik Community in Klaten)
}

\author{
Purwanti Asih Levi \\ Environment and Urban Studies, Universitas Katolik Soegijapranata, Indonesia \\ Arianti Ina Restiani Hunga \\ Pusat Studi Gender dan Anak, Universitas Kristen Satya Wacana, Indonesia \\ Hotmauli Sidabalok \\ Environment and Urban Studies, Universitas Katolik Soegijapranata, Indonesia \\ Corresponding email: ina.hunga@uksw.edu
}

\begin{abstract}
Mass and rapid batik production using synthetic color and printing techniques engenders environmental problems - such as waste production, air and water pollution, as well as unhealthy and hazardous work environment-and a threat to the sustainability of hand-drawn batik. Clean production is one solution to this problem. This paper discusses the practice of batik making with natural coloring based on the theory of clean production with an ecofeminist perspective. The method employed in this research is a case study with a one-unit production (cluster) approach of Putri Kawung batik community. The findings show that the practice of clean batik production in Putri Kawung batik community still focuses on the input and process of natural coloring, material selection, and reuse of wax materials. This shows that the role of women through community gradually practices clean production, even though it has not yet extended to its output processing.

KEYWORDS: batik, hand-drawn batik, natural color batik, eco-friendly batik, environment, clean production, ecofeminism.
\end{abstract}

\section{RESEARCH BACKGROUND}

Batik is an Indonesian cultural heritage that UNESCO has designated as a Representative List of The Intangible Cultural Heritage of Humanity on October 2, 2009. To respond to the conferral of batik as a Cultural Heritage by UNESCO, the Indonesian government has set October 2 as the National Batik Day
(Hari Batik Nasional). Furthermore, the government has also set batik as the official clothing worn by civil servants on weekdays (https://kemenperin.go.id).

Historically, batik was originally produced using natural materials from various plants (e.g., wood, roots, leaves, and stems) that could be found from the surrounding 
environment, and the production process highly involved women. The industrialization of batik implicated the choice of replacing natural materials with synthetic materials. Besides, instead of using canthing as the tool to draw batik traditionally, stamps and prints are utilized. Synthetic dyes have slowly substituted the role of natural dyes in batik production (Sekawan Susanto 1973).

Batik is devalued as a mere economic commodity. The original hand-drawn batik contrasts the image of textile batik (printed batik), which is machine-produced, oriented towards mass production, of lower prices, emphasizes the image of batik as a commodity, and involves more male workers. In fact, hand-drawn batik is the complete opposite: it uses wax as its main material and gives more space for exploration by female batik makers. The emergence of textile batik indeed endangers the uniqueness of Indonesian batik, which has sociocultural values (Susanto, 1973). The technique production of textile batik (printed batik) requires the investment of large equipment, which may be affordable for medium-large scale industries. Undeniably, only medium-large scale industries will benefit from this system, and this can 'exterminate' micro, small, and self-employed batik industries (Penelitian, 2004).

Furthermore, the original batik produced in the country could not compete with the imported textile batik. According to industry news, the Ministry of Industry stated that in 2012, Indonesia imported batik fabrics and finished batik products from China, amounting to US\$30 million or IDR 285 billion (http://www.kemenperin.go.id/artike 1/5715/2012). According to the Central Statistics Agency (Badan Pusat Statistik/BPS), in 2012, there were 1,037 tons of batik products imported from China to Indonesia. The Association of Indonesian Batik Craftsmen and Entrepreneurs (Asosiasi Perajin dan Pengusaha Batik Indonesia/APPBI) mentioned that illegal importers imported reproduction batik from China and India to Indonesia. Chinese batik is commonly imported to Indonesia in the form of fabric rolls. According to the Central Statistics Agency, between 2016 and 2018, the volume of imported fabrics continued to increase with a trend of $31.8 \%$. In 2016, the import of fabrics (including imitation batik) were recorded at 238,219 tons; then, in 2017 , it rose to 291,915 tons and continued to rise to 413,813 tons in 2018. This is an irony and a heavy blow because batik is an original Indonesian product and considered as the identity of Indonesian culture (https://www.cnbindonesia.com/new s/201910020161418-4-

103920/benarkah-batik-chinamasih-merajalela).

Mass and rapid batik production using synthetic color and printing techniques engenders environmental problems-such as waste production, air and water pollution, unhealthy and hazardous work environment-and a threat to the sustainability of hand-drawn batik. The process of making both hand-drawn and stamped batik cannot be separated from the use of dyes. In fact, the most widely used are synthetic dyes which have negative impacts on nature, the environment, and humans (i.e., producers, workers, and consumers). 
The image of batik is challenged by the fact that the production process is no longer environmentally friendly; instead, it produces hazardous waste that threatens nature and human life. Every year, the batik industry pays the highest levels of $\mathrm{CO} 2$ emissions among other SME sectors, which is generally the result of the industry's dependence on fuel (kerosene) and the high use of electricity. Also, a large number of batik SMEs still use excessive wax, synthetic dyes, and bleach, which have negative impacts on the environment and its surrounding society (Initiative, 2013). This fact becomes worrying because most batik production process occurs in the residences of its workers, instead of in factories/workshops, especially for micro-scale and self-employed batik industries. Production waste becomes a burden for the whole family, especially for women and children who are mostly active at home.

Batik industry has a lot of potential for pollution, including solid and liquid waste as well as air emissions. The Ministry of Environment and Forestry stated that the batik industry is the biggest contributor to polluting rivers. One batik SME produces around 125 liters of liquid waste per kilogram of batik in Yogyakarta (Yulianto, 2012 in Apriyani, 2018) and around 100 liters of liquid waste per kilogram of batik in Pekalongan (Wicaksono, 2012 dalam Apriyani 2018). The use of synthetic materials in the batik industry has a high potential to produce waste containing heavy metals, which are categorized as hazardous waste and can cause environmental pollution. The increase in batik production also escalates environmental problems. This problem is mainly due to the production process, in which it often uses excessive materials and energy, and improper waste disposal due to the increase of waste processing costs.

A problem in the production process is the use of synthetic dyes, and as a result, the waste will be harmful to the health of batik workers and its surrounding environment. The substance of liquid waste produced by the batik industry contains organic substances, suspended solids, phenol, chromium (Cr), fatty oils, and colorants (Kep. Gubernur Kepala DIY. No:281/KPTS/1998). Some types of dyes produced during the washing process of a batik fabric also contain heavy metals such as chromium, which in water can damage the water quality and harm the environment and its aquatic organisms. As for humans, it can cause ulcers on the nose and skin, skin hyperpigmentation, skin cancer, and renal tubular necrosis. Furthermore, the impact of excess chromium in the body will also occur in the respiratory tract, kidneys, and liver. The effect on the respiratory tract includes lung irritation due to long-term inhalation of chromium dust. Besides, chronic irritation, polyps, tracheobronchitis, and chronic pharyngitis could also be triggered (https://media.neliti.com).

As described above, these issues within the industry are even more precarious because most production processes occur at the household/private residence sphere or in communities (batik cluster) through a system commonly called 
the Putting-Out System (POS). Batik industry has been employing the POS for a long time. Workers who work under the system mode of production are known as homeworkers (ILO, 1996; Hunga, 2014). Batik homeworkers receive work from a batik central agent (the industry owner), in which they then work at off-site facilities, such as their own houses or residential area. After they finish the work, the workers will deliver it back to the central agent. They work without direct supervision from the owner, and they are also paid based on finished units such as sheets, scores, meters, etc. The Putting-Out System has been growing since the 1998 economic crisis and has become an alternative production system that benefits entrepreneurs because it is efficient. Since most production process occurs in the workers' private residential area, this also means that production waste moves or is moved into or around the workers' homes, which was previously produced at on-site facilities (Hunga 2011). This process persists, and hazardous production waste is released into nature which damages the soil and its ecosystem. Batik production waste polluting the homeworkers' residential area negatively impacts their health, especially children's and women's, because they are more active. As most production process occurs at the workers' private residential areas and they spread out in one unit of batik production centers (cluster), the workers' family predominantly suffer from the negative impacts of solid and liquid waste produced during the batik production process (Hunga, 2011).
Clean production is one solution to this problem. The principle of clean production specifically contributes to the implementation of the production process that considers sustainability, which is the essence of environmental justice. However, this theory does not discuss the subject of the production process who, in this case, are batik workers that practice their knowledge and skills according to the gender construction of the society. Therefore, integrating gender issues and construction in the conceptual and theoretical framework becomes crucial, in which we integrate ecofeminist theory. This paper discusses the practice of natural color batik production by implementing clean production theory with an ecofeminist perspective. Further, the study aims to describe the practice of batik using natural color reviewed based on clean production theory with ecofeminist perspective.

\section{RESEARCH METHOD}

The research method used in this paper is a combination of case study research conducted in Putri Kawung batik community. The primary data are gathered through participatory technique. To support the depth of understanding both conceptually and methodologically, this paper also employs a review of relevant concepts, literature review, and study of secondary data from various sources relevant to this topic. Furthermore, to look at the application of clean technology, we also investigate the production chain related to the batik production process. 


\section{RESULT AND DISCUSSION}

\section{Clean Production Based on an Ecofeminist Perspective}

UNEP (2003, in Purwanto, 2005) defined clean production as a preventive and integrated environmental management strategy that needs to be applied continuously in the production process and product life cycle to reduce hazardous risks to humans and the environment. Clean production aims to a) achieve production/service efficiency through efforts to save material and energy use and b) improve environmental quality through waste minimization efforts.

According to a study (Purwanto, 2005), the indicators for the success of implementing clean production in the industry include: 1) reduced use of water, in which the industry has excess water supply, 2) increased energy efficiency, in which the industry has excess power and can still be utilized further, 3) management of industrial waste that can be used as raw material, and 4) decreased production of liquid and solid waste, in which the industry has excess capacity of wastewater treatment plant (WWTP) and incinerator.

There are seven key factors in clean production, which include a) reducing the amount of material used in the production, b) reducing the amount of energy use, c) reducing pollution, d) increasing materials recycling, e) maximizing the use of renewable natural resources, f) extending product life cycle, and g) increasing service intensity (World Business Council for Sustainability Development, 2007 in Purwanto, 2005).
The main principles in clean production strategy as mentioned in the National Clean Production Policy (Kebijakan Nasional Produksi Bersih) (KLH, 2003, in Purwanto, 2005) include: (1) eliminating or preventing, (2) rethinking, (3) reducing, (4) reusing, (5) recycling, (6) recovering or reclaiming, (7) replacing or substituting the use of an item or use alternative ecofriendly and reusable goods, and (8) repairing. These eight clean production strategies are parts of clean strategies by the Ministry of Environment and Forestry in 2003. By considering the objectives of this study, we add two clean production strategies; they are (1) replanting and (2) revitalizing values. Based on this explanation, this study will use ten indicators in total.

A study emphasized the benefits of implementing clean production (Bratasida, 1996, Helmy, 1997 in Purwanto, 2005). First, clean production practices can prevent pollution and environmental damage through efforts to minimize waste, recycle process, and safe waste disposal. Secondly, it supports the principle of Environmental Protection in Sustainable Development Goal (SDG). Thirdly, it can also increase economic growth by implementing efficient production processes and the use of raw materials and energy in the long term. Fourth, it can prevent or slow environmental degradation and reduce the exploitation of natural resources through waste recycling during production, which ultimately leads to the conservation of natural resources to achieve SDG. Fifth, it can also provide opportunities for economic benefits because a clean production strategy focuses on 
preventing pollution at its source (source reduction and in recycling), which is to prevent early waste production, thereby reducing investment costs that must be incurred for waste treatment and disposal or the cost for environmental improvement. There are two aspects of economic opportunities, which are a) strengthening production competitiveness in the global market and b) improving the image of producers and increasing consumer confidence in the products produced. Lastly, it can reduce the level of occupational health and safety hazards. The practices and actions of clean production practices also include applying technology that can prevent or reduce waste generation, which comprises soft technology and hard technology. According to US EPA, clean production measures include product changes and process changes, including input material change, technology change, and improved operating practices.

A critical attitude towards ecological crises that negatively affect women was initiated by Francoise d'Eaubonne in her book $L e$ Feminism ou la Mort (Feminism or Death), published in 1974. This was the beginning of the term ecofeminism, although the term was officially introduced in the 1980s. Ecofeminism became popular during the protests against environmental destruction and ecological disasters (Shiva and Mies, 1993). Francoise d'Eaubonnebon (1974) revealed that there was a close correlation between women's oppression and nature, which can be studied through cultural, economic, social, and political aspects. King and
Ynestra (1983) emphasized the dialectic between the oppression of women and nature by men. This oppression is rooted in a patriarchal culture, and in this system, women and nature occupy the same position (construction) as objects instead of subjects. Karen J. Warren (Warren 2016) developed ecofeminism in a conceptual, methodological, and practical framework, rooted from women's perspective on ecological crises focused on studying, criticizing, and finding solutions in the interconnection of women, nature, and humans for gender equality and environmental continuity. In their book Ecofeminism, Shiva and Mies (1993) argued that the ecofeminist movement and philosophy is a criticism of development approaches that do not consider ecological sustainability and marginalize certain entities (e.g., women). Therefore, ecofeminism is brought to solve human and environmental problems based on women's experiences and make them a source of learning to manage and conserve nature. It also means providing more equitable and equal space (and access) for women in collaboration with men in managing and conserving nature.

The issues of feminism and ecology are historically intertwined. Women are always associated with nature; therefore, women are conceptually, symbolically, and linguistically identified with nature. Karen J. Warren (Warren 2016) stated that this association is closely related to social construction, which is formed by values, beliefs, education, and behavior based on patriarchy, in which the justification of domination, subordination, and 
oppression of women by men exists. Because women are equated with nature, there is an important relationship between domination over women and nature. Androcentric and anthropocentric views and practices cause the current ecological damage. Ecofeminism philosophers believe that the basic concept of dual domination over nature and women is a duality and hierarchy of values. Therefore, the role of feminism and environmental ethics is to uncover and dismantle these dualisms and recast their underlying philosophical ideas. Thus, feminism and ecology movements will have mutually reinforcing objectives; both want to build a new worldview that is not based on patriarchal models and domination (Hunga, 2014).

Ecofeminists also reveal that the gender roles assigned to women give them more "sensitivity" and "proximity" to nature. In a society that uses nature and earth as the source of life, humans are created through a relationship, in which it is not only based on matter but also the earth and society. The earth and its inhabitants are united in an intimate interconnection (Shiva, 2005). On behalf of construction and development, the approach used focuses only on economic growth; it dissolves the intimate relationship between man and nature, turning it into a material relationship. In the midst of an ecological and interhuman (gender) crisis, it is urgent to create critical education to "completely change" the values or concepts that build mindsets, redefine and revise (by creating new interpretations), explore positive local values, and change them into real actions that will accomplish gender equality within the context of environmental management and preservation.

Therefore, a shared commitment is needed to create a "social and cultural" participatory movement based on the experiences of women and other marginalized groups to manage and preserve "the forgotten" and "deliberately marginalized" nature. Ecofeminism is a "social movement" as a response to the ecological crisis and a critique of construction approaches that ignore ecological sustainability and marginalize certain human entities, specifically women. Ecofeminism is a dialectic that emphasizes the concept (theory) and practices to solve the crisis of relations among humans and of humans and nature. In this case, this is accomplished by changing the system and societal structure, which places men, women, and nature into an integral-holistic unit. Therefore, there is a correlation between the economy and social justice, gender equality, and the environment, and peace must prevail (Hunga, 2014).

Clean production is one solution to this problem. The principle of clean production specifically contributes to the implementation of the production process that considers sustainability, which is the essence of environmental justice. However, this theory does not discuss the subject of the production process who, in this case, are batik workers who practice their knowledge and skills according to the gender construction of society. Therefore, integrating gender issues and construction in the conceptual/theoretical framework becomes crucial, in which we integrate ecofeminist theory. This paper discusses the 
practice of natural color batik production by implementing clean production theory with an ecofeminist perspective.

In this study, ecofeminism theory is used to analyze the relationship between humans and the crisis of relations between humans and nature in batik production of batik industry based on the POS. Based on the analysis, we can obtain an overview of the experiences of female batik makers. Consequently, we can also highlight their experiences as learning resources in managing and conserving nature. The research will also provide more equitable and equal space (and access) for women in collaboration with men in managing and conserving nature.

\section{Clean batik based on an ecofe- minist perspective}

There are three interrelated dimensions in the batik industry with the POS: 1) human resources for batik makers and business owners, 2) batik products, and 3) the environment affected by the production process.

In this study, the researchers describe the daily practices in the production of natural dyed batik by Putri Kawung batik community. Putri Kawung batik community is a group of 20 batik artisans who produced natural dyed batik in the batik cluster in Klaten. Most of the members of the group are female artisans. The researchers studied three parts of natural dyed batik production practices, namely 1) Material Input Practices, to determine clean production practices in the use of raw materials, energy, 2) Production Process Practices, to find out clean production practices in production activities, and 3) Output Management Practices, to find out how to manage output, including both product and non-product (waste) output.

Putri Kawung batik community buy raw materials, such as plain white fabric, wax materials, coloring materials, and other equipment for the production, in Solo. They usually purchase these raw materials every two to three weeks. The amount of purchase depends on how much money they own. They have to buy raw materials and batik equipment in Solo because there is no batik shop available in Desa Jarum. They buy raw materials in large quantities and sell some to other batik makers at retail price. The batik makers choose white cloth called primissima, 100\% cotton fabric made from natural and high-quality material. They prefer this type of fabric because it is easy to draw on, is easily pasted with wax, and easily absorbs the natural coloring. Besides, upon worn, it is a moisture-wicking fabric and feels cool on the skin. They also buy high-quality wax materials because they will be pasted on fabric more easily and firmly (which does not seep into the fabric) and can be recycled and reused repeatedly. They also buy natural coloring materials instead of planting floras for colorant. They prefer not to use natural coloring materials that can be derived from plants in their surrounding area because they do not want to experiment on uncertain materials as it will take more time.

Putri Kawung batik community discovered an innovation to replace 
carbon paper with langes ${ }^{1}$ carbon. They make their own langes carbon, considering its sustainability (i.e., it can be made into various sizes depending on one's needs), its durability, and that it can be passed on to posterity (heirloom value). Putri Kawung batik community uses canthing and brushes to apply wax to the fabric. They usually buy both tools in Solo. Canthing is used to paste wax to images such as lines, curves, and points, while brushes are used to apply wax in large, filling areas. Batik makers prefer to use good quality canthing and brushes considering its sustainability and durability. After each use, they boil these canthing and brushes to remove the wax residue. It can be concluded that the batik makers have implemented the principles of clean production by selecting highquality white fabric, high-quality wax material, and natural coloring materials. However, the purchases that must be made outside the city can still cause carbon emissions. Likewise, they have not attempted to plant their own coloring materials.

In terms of electricity supply, it can be concluded that Putri Kawung batik community uses electricity and electric pumps to garner water supply and provide lighting. Most batik makers only have one electricity meter, so there is no separation of electricity use for

\footnotetext{
${ }^{1}$ langes is homemade carbon made from black smoke residue from combustion. Putri Kawung batik community makes their own carbon langes by lighting a kerosene lamp with a large wick. Above the lamp a zinc sheet or plate is placed to collect the langes that come out of the lamp smoke. Langes that are accumulated in the sheet are collected in a basin, then mixed with kerosene and oil. It is then stirred evenly and applied to cotton cloth with sizes varying between $70 \times 70$ $\mathrm{cm}$ to $120 \times 120 \mathrm{~cm}$. Once dry, the homemade carbon langes are ready to use.
}

production and household purposes. To supply the water, Putri Kawung batik community uses soil water from artesian wells for both production and household activities. They use an automatic electric pump, and the water is stored in reservoirs and sinks. They do not pour water into the tubs every day because the water in the sink will only be replaced if it is murky due to the residue of coloring and wax material.

During the production process, Putri Kawung batik community work on making batik designs and patterns at the designers' house. The process for cutting and sewing will be carried out at the tailors' house, and it is specifically done by professionals to avoid making wrong cuts. Furthermore, the fabric scraps can also be used to make craft items such as prayer mats, wallets, and bags. The work of copying or tracing the images, or ngeblat in Javanese, from design papers to fabric is done at the draftsmen's houses. They trace the image using homemade carbon called langes carbon to substitute paper. These langes carbon can be made into various sizes depending on the needs, and it is more durable and can be recycled. The work of handmarking or applying wax on the patterned fabric, or menyanthing, is carried out in the workshops and at the workers' private residences. The remaining wax materials scattered during this process are collected and recycled to be reused. The process of color extraction, coloring, removing unused wax from cloth (nglorod, Javanese), cloth washing, quality control, and finishing are carried out in the workshop. In conclusion, batik makers of Putri Kawung batik community have implemented the 
principles of clean production, including cutting fabric as needed, and the fabric scraps are used to make new goods of economic value. They also collect and recycle wax materials residue to be reused.

Putri Kawung batik community manage the finished products in the showroom. Batik fabric products are stored with vetiver preservative. Other non-product outputs as the result of the production include fabric scraps, wax, water, and gas. Fabric scraps are used to make prayer mats, wallets, and bags. Wax waste is reused for second and third batik production. Unprocessed water waste is directly disposed of into septic tanks and sewers. The impact of gas waste is minimized by making outdoor workshops without walls so that the emitted smoke from the combustion can be blown directly by the wind.

Based on the above explanation on product and waste management, Putri Kawung batik community have implemented the principles of clean production in the management of batik products by giving preservatives from natural ingredients (i.e., vetiver), which keeps moths away while aromatizing the finished batik products. In the management of gas waste, they also have attempted to minimize its environmental effects by working in open spaces. However, they have not managed the liquid waste properly, as they only dispose it into septic tanks.

In this study, ecofeminism theory is used to analyze the correlation between humans and the crisis of relations between humans and nature in the practice of batik industry. The findings of this study will discover an overview of female batik makers' experiences and make their experiences a learning resource in managing and conserving nature. It also means providing more equitable and equal space and access for women in collaboration with men in managing and conserving nature. Putri Kawung batik community divide the roles according to the capacity of each batik maker. Even though most of the members of this community are women, men are also involved in the production, such as during cleaning unused wax from fabric and coloring. Thus, men are not excluded from the production process at home, and on the other hand, they are equally empowered.

The involved human resources during batik production process cannot be separated from the gender aspects attached to them. Batik is a product that is socio-culturally attached to the stereotypes of women. In the batik industry with Putting-Out System, the term "homeworker" does not merely mean that a worker receives a job from the central agent, brings the job home, finishes the job at home, and returns the finished products to the central agent. This term also creates a discourse over the fact that most of these workers are married women and have children. The house is not only a workplace, but it also becomes a symbol of women's domestication to fulfil their domestic roles as housewives and care for their family members. In contrast to men who are considered as the breadwinner, women are considered only as complementary in earning additional salary. Therefore, it is natural for these 
women to have lower wage because their productive work is considered part-time. It is only done when they already finish their household work. It is obvious that the discourse is encouraged by the stereotypes of women loaded with gender ideology (Hunga, 2001).

In batik industries that employ the Putting-Out System, the production process takes place at home and its surrounding areas, traditionally considered as a domestic sphere in a household. Society recognizes public and private spheres, and these two spheres were strictly separated in terms of physical or material and concept or value. The public sphere represents workspace (either a factory or a workshop), and it is productive and contributes to monetary value. Besides, it is the main place for men as breadwinners. This sphere is considered capitalist, a place in which capitalist production occurs. On the other hand, the domestic sphere is unproductive, has no monetary value, and is a place for homemakers or wives to provide services to their husbands and children as an expression of obedience to patriarchal values and a place in which patriarchal production occurs.

Within the context of the PuttingOut System, when batik production activities occur at workers' homes or in the domestic sphere, a contradiction occurs-both batik production (for the industries) and waste production also occur. This has negative implications towards several aspects such as environmental health, comfort, and privacy of homeworkers' families, especially for women and children who are more vulnerable and spend more time at home. At the same time, domestic production also takes place in those spheres, such as cooking, washing, raising children, and other reproductive activities carried out by women for an extended period (Hunga 2014).

The theory of clean production is used to analyze batik production practices done by batik makers and investigate whether the production process has employed the principles of clean production. Clean production theory is used to analyze batik production practice through the input workflow of knowledge, skills, materials and tools, production processes, and finished products and non-products outputs. Preventive variables, increasing efficiency, and reducing waste are seen through clean production strategies and actions to achieve clean production performance indicators. The indicators include the use of natural dyes, reduced water use, reduced waste, reduced energy use, reduced use of raw materials, reduced $\mathrm{CO} 2$ emissions, chemical management, and the application of Occupational Safety \& Health (OHS) (SWITCH Asia, 2010). The accomplishment of these indicators will provide economic benefits (in the form of profit), society (people), and the environment (planet).

\section{SUMMARY}

The practice of clean batik production in Putri Kawung Batik Community still focuses on the input and process of using natural color, material selection, and reuse of wax materials. This shows that the role of women through community gradually practices clean production, 
even though it has not yet extended to its output processing.

The principle of clean production specifically contributes to the implementation of the production process that considers sustainability, which is the essence of environmental justice. However, this theory does not discuss the subject of the production process who, in this case, are batik workers who practice their knowledge and skills according to the gender construction of society. Therefore, integrating gender issues and construction in the conceptual/theoretical framework becomes crucial, in which we integrate ecofeminist theory.

\section{REFERENCES}

Apriyani, Nani. 2018. "Industri Batik: Kandungan Limbah Cair Dan Metode Pengolahannya." Media Ilmiah Teknik Lingkungan 3(1):2129.

Hunga, Arianti Ina R. 2014. “Ancaman Kerusakan Ekologis Produksi Batik Rumahan: Narasa Perlindungan Ruang Domestik." Jurnal Perempuan 80 19(1):27-52.

Hunga, Arianti Ina Restiani. 2011. "Menanti Pengakuan: Industri Batik Berbasis Putting-Out System Dan Home-Workers." Interdiciplinary Social Sciences 5(9).

Hunga, Arianti Ina R. 2014. "Protecting Women's Domestic Area \& Environment: Study on EcoFriendly Batik." Indonesian Femininst Journal 2(2):82-105.
Initiative, Clean Batik. 2013. "Clean Batik Initiative Location: Duration: Indonesia ( 6 Provinces ) Malaysia ( 2 Provinces) Poor Chemical Handling."

Keputusan Gubernur Kepala DIY. No:281/KPTS/1998

Penelitian, Tujuan. 2004. "Eksistensi Pekerja Rumahan Di Industri Kecil-Menengah Berbasis ‘ Putting - Out' System ( Studi Kasus Di Industri Batik Bebasis ‘ Putting - Out' System Dalam Klaster Batik Id Jawa Tengah ) Oleh Arianti Ina Restiani Hunga." $1-4$.

Purwanto. 2005. "Penerapan Produksi Bersih Di Kawasan Industri." Seminar Penerapan Program Produksi Bersih Dalam Mendorong Kawasan Eco-Indstri Di Indonesia 1-10.

Susanto, Sekawan. 1973. "Seni Kerajinan Batik Indonesia.” 18.

Shiva, Vandana dan Maria Mies. 2005. Ecofeminism Perspektif Gerakan Perempuan dan Lingkungan. Alih Bahasa oleh Kelik Ismunanto. Yogyakarta: IRE Press.

Warren, Karen. 2016. "Nature Is a Feminist Issue BT - A Western Perspective on What It Is and Why It Matters." A Western Perspective on What It Is and Why It Matters (1):1-19.

http://www.kemenperin.go.id/artikel/57 $15 / 2012$

https://www.cnbindonesia.com/news/20 1910020161418-4103920/benarkah-batik-chinamasih-merajalela

https://media.neliti.com 


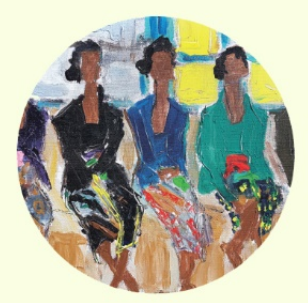

\section{ABOUT}

SALASIKA etymologically derived from Javanese language meaning 'brave woman'. SALASIKA JOURNAL (SJ) is founded in July 2019 as an international open access, scholarly, peerreviewed, interdisciplinary journal publishing theoretically innovative and methodologically diverse research in the fields of gender studies, sexualities and feminism. Our conception of both theory and method is broad and encompassing, and we welcome contributions from scholars around the world.

$\mathrm{SJ}$ is inspired by the need to put into visibility the Indonesian and South East Asian women to ensure a dissemination of knowledge to a wider general audience.

SJ selects at least several outstanding articles by scholars in the early stages of a career in academic research for each issue, thereby providing support for new voices and emerging scholarship.

\section{AUDIENCE}

SJ aims to provide academic literature which is accessible across disciplines, but also to a wider 'non-academic' audience interested and engaged with social justice, ecofeminism, human rights, policy/advocacy, gender, sexualities, concepts of equality, social change, migration and social mobilisation, inter-religious and international relations and development.

There are other journals which address those topics, but SJ approaches the broad areas of gender, sexuality and feminism in an integrated fashion. It further addresses the issue of international collaboration and inclusion as existing gaps in the area of academic publishing by (a) crossing language boundaries and creating a space for publishing and (b) providing an opportunity for innovative emerging scholars to engage in the academic dialogue with established researchers.

\section{STRUCTURE OF THE JOURNAL}

All articles will be preceded by an abstract (150-200 words), keywords, main text introduction, materials and methods, results, discussion; acknowledgments; declaration of interest statement; references; appendices (as appropriate); table(s) with caption(s) (on individual pages); figures; figure captions (as a list); and a contributor biography (150 words). Word length is $4,000-10,000$ words, including all previous elements.

\section{TIMELINE AND SCHEDULE}

Twice a year: February and July.

\section{PUBLISHING AND COPYRIGHT APPROACH}

All articles must not have been published or be under consideration elsewhere. We are unable to pay for permissions to publish pieces whose copyright is not held by the author. Contributors will be responsible for clearing all copyright permissions before submitting translations, illustrations or long quotes. The views expressed in papers are those of the authors and not necessarily those of the journal or its editors.

\section{CONTENT ASSESSMENT}

All articles will be peer-reviewed double-blind and will be submitted electronically to the journal (journal@salasika.org).The editors ensure that all submissions are refereed anonymously by two readers in the relevant field. In the event of widely divergent opinion during this process a third referee will be asked to comment, and the decision to publish taken on that recommendation. We expect that the editorial process will take up to four months. We will allow up to four weeks for contributors to send in revised manuscripts with corrections.

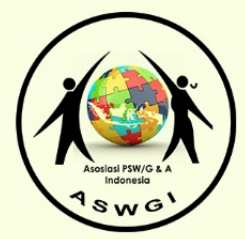

Published by:

\section{THE INDONESIAN ASSOCIATION OF} WOMEN/GENDER \& CHILD STUDIES.

The Centre for Gender \& Child Studies

Universitas Kristen Satya Wacana (CGCS UKSW).

Jl. Diponegoro 52-60, Salatiga, 50711.

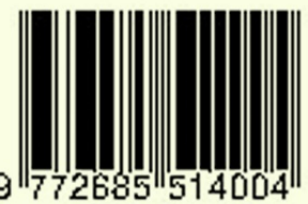

